\title{
Survival of Lac Insects (Kerria lacca Kerr.) on Cajanus cajan (L) Millsp.
}

\author{
Sumit Kakade $^{1 *}$, Rahul Patidar ${ }^{1}$, Shivam Vajpayee ${ }^{1}$, Moni Thomas ${ }^{2}$, Niraj Tripathi ${ }^{2}$, \\ A. K. Bhowmick ${ }^{1}$, Anubha Upadhyay ${ }^{3}$, A. K. Mandal ${ }^{4}$, H. L. Sharma ${ }^{5}$ and Sanjay Singh ${ }^{6}$ \\ ${ }^{1}$ Department of Entomology, ${ }^{2}$ Directorate of Research Services, ${ }^{3}$ Department of Plant \\ Physiology, ${ }^{5}$ Department of Statistics, ${ }^{6}$ Department of Genetics and Plant Breeding, College \\ of Agriculture, Jawaharlal Nehru Krishi Vishwa Vidyalaya, Jabalpur, India \\ ${ }^{4}$ Indian Institute of Soil Sciences, Bhopal, India \\ *Corresponding author
}

\section{A B S T R A C T}

Keywords

Survival, Kerria lacca, Cajanus cajan, Farmers, Phloem feeder, Phytophagous insect

\section{Article Info}

Accepted:

04 November 2020 Available Online: 10 December 2020
Growth and health of plants depends on the health substrate or soil, while growth and survival of phytophagous insects depends on the health of its host plants. Similarly, growth and survival of phloem feeders, including Lac insects (Kerria lacca) depends on the quality and quantity of phloem sap access to it. $K$ lacca produce natural resin which is a cash crop and commodity of export. Commercially, $K$ lacca is reared on the naturally standing trees of Butea monosperma, Zizyphus mauritiana and Schleicheria oleosa. But when it is reared on cultivated annual shrubby hosts like Cajanus cajan, soil health matters. In this context, a field experiment was conducted by rearing $K$. lacca on $C$. cajan grown on different substrates. The data reveals that the substrate combination of Kapu $(45 \mathrm{~kg})+$ FYM $(20 \mathrm{~kg})+T$. viride was the best as it produced highest lac $(288.33 \mathrm{~g})$ and seed yield $(838.33 \mathrm{~g})$ of $C$. cajan. The survival percent of Lac insect from brood lac inoculation to the harvest of lac crop was highest $(41.83 \%)$ on $C$. cajan grown on Карu $(45 \mathrm{~kg})+$ FYM $(20 \mathrm{~kg})+T$. viride. The study indicates the substrate play a major role in the growth of the host plants and survival of $K$. lacca.

\section{Introduction}

Survival and growth of insects depends on the availability of food (McGuinness, 1987; Gogi et al., 2012) and protection in an ecosystem (Yumamura et al., 2006; Ayers et al., 2009), quality (Gimnig et al., 2002) and quantity (Okech et al., 2007)) of the food is essential for the growth and survival of insects. Among herbivores, there are foliage feeders (Douglas, 2003), phloem feeders (Kehr, 2006), stem borer (Heinrichs et al., 2004) fruit borers (Thomas, 1992) and even root feeders (Potter et al., 2002).

Lac is secreted by Kerria lacca Kerr. (Colton, 1984) while feeding on the phloem sap (Kehr. 2006; Kaushik et al., 2012) of the host range of over 250 plants (Roonwal et al., 1958; Sharma). Commercially $K$. lacca is reared on Butea monosperma (Sharma et al, 2015) Zizyphus mauritiana (Shah et al., 2014, 
Namdev, 2015), Schleicheria oleosa (Roonwal, 1962), Flemingia semialata (Kumar and Rani, 2019) as well as Cajanus cajan (Thomas, 2003). Phloem is an important mediator of whole plant communication (Ruiz-Mrdrano et al., 2001). Plant nutrients are translocated through phloem tissue as phloem sap (Douglas, 2003). The quality and quantity of phloem sap influences the growth and survival of phloem feeders (Cisneros and Godfrey, 1999) like $K$. lacca (Mengel and Kirkby, 1987). Lac production is also dependent on the phloem sap accessible to Lac insect. Earlier workers have studied Lac production in context to Lac basal application of nutrients (Namdev et al., 2016, Shah et al., 2014) and foliar application (Sharma et al., 2015; Gurjar et al., 2016; Ghugal et al., 2016). Thus, the present field trial conducted to study the survival of Lac insect on $C$. cajan growth on different combination of substrate treated with soil microbes.

\section{Materials and Methods}

Survival of $K$. lacca on $C$. cajan grown on different substrate combination was evaluated in field trial in Jawaharlal Nehru Krishi Vishwa Vidyalaya, Jabalpur, Madhya Pradesh. The field trial was conducted from June 2018 to June 2019.The topography of the experimental area was fairly uniform. The Randomised Block Design experiment had seven treatments and three replications of $C$. cajan variety TJT- 501. Plant to plant and row to row spacing was $6 \mathrm{ft} \mathrm{x} 6 \mathrm{ft}$. There were three plants per replication in of each of the seven treatments (Table 1).

Weather: The weather of Jabalpur region is typically Sub humid, characterised by hot dry summer and cool dry winter. It is favourable for the growth and development of $C$. cajan. The total rainfall received during the crop season was $1162.90 \mathrm{~mm}$, in 58 rainy days from July 2018 to last week of May 2019. The mean daily temperature ranged from minimum $4.80^{\circ} \mathrm{C}$ to $24.90^{\circ} \mathrm{C}$ and maximum 28.5 to $41.80{ }^{\circ} \mathrm{C}$ during the year 2018-2019.

Substrate: The seedlings of $C$. cajan was transplanted in used polypropylene bags $(\mathrm{PPB})$ of size $93 \mathrm{~cm} \times 61 \mathrm{~cm}$ filled with substrate (Patent appl.no.201921005340A). There were three types or combination of substrates used for the present field experiment. Substrate- $S_{1}$ consisting of a mixture of $45 \mathrm{~kg}$ river bed basin soil (Kapu) and $20 \mathrm{~kg}$ well rotten Farmyard manure $(\mathrm{FYM})+$ Trichoderma viride), Substrate- $\mathrm{S}_{2}$ consisted45kg (FYM) + Trichoderma viride) and Substrate- $\mathrm{S}_{3}$ was $65 \mathrm{~kg}$ (Table 3) river bed basin soil $($ Kapu $)+$ Trichoderma viride) The Kapu and FYM in the above ratio was thoroughly mixed with the help of a spade to obtain a homogenised substrate.

The physio-chemical property of the substrate is mentioned in the table (3). The substrate was gradually filled into the PPB with help of a tasala followed by constant shaking the bag to ensure proper settlement and compactness of the substrate in it. The $65 \mathrm{~kg}$ substrate filled PPB attains a dimension of $46 \mathrm{~cm}$ height and $125 \mathrm{~cm}$ circumference. The PPB was filled with substrate on the designated spot in the layout of the experiment for clarity.

\section{Nursery raising of sapling}

Nursery of $C$. cajan was raised in the month of May 2018 in the substrate $($ Kapu + FYM) filled perforated polythene bag $(18 \times 16 \mathrm{~cm})$ by sowing seeds treated with $T$. viride. Polythene bags were irrigated at weekly intervals. The seedlings were sprayed with insecticides to prevent insect pest incidence. The growing tips of the seedlings were nipped at 10-12 days interval till its transplantation. 


\section{Transplantation of $C$. cajan saplings}

C. cajan seedling on attaining a height varying from 1.5 feet to 2 feet were transported to the main field. Each of the 63 seedlings were placed at the base of substrate filled PPB.

The polythene bag of the $C$. cajan seedling was carefully removed without disturbing its root system of the seedling. The seedling with substrate base was carefully transplanted in the PPB and pressed tightly from all corners, followed by watering. The transplantation was done in the evening hours of $15^{\text {th }}$ August 2018.

\section{Brood Lac inoculation (BLI)}

Rangeeni brood Lac purchased from M/s Adarsh Lac Samiti, Jamankhari village, Tehsil Barghat, District Seoni, Madhya Pradesh, on 03.11.2018. The brood Lac was sorted for predators free and good quality before inoculation on $C$. cajan. Brood Lac stick weighing $15 \mathrm{~g}$ was tied at the base of each $C$. cajanin the PPB on with the help of a twine as per the treatments scheme of the experiment.

\section{Lac insect count}

Live Lac insects were counted per $2.5 \mathrm{~cm}^{2}$ $(2.5 \mathrm{~cm}$ length and $1.0 \mathrm{~cm}$ width) space marked on the Lac insect settled branches of C. cajan.

\section{Marking of slot}

Usually by 30 days of BLI, majority of the nymph of $K$. lacca leaves the brood Lac and settles on the succulent branches of the host plant. Lac insect inserts its stylets into the phloem tissue and becomes sedentary. Thus, thirty days after BLI, branches with good Lac insect settlement were randomly selected for marking of slot. A slot of $2.5 \mathrm{~cm}^{2}(1 \mathrm{~cm} \mathrm{x}$ $2.5 \mathrm{~cm}$ ) was marked on the bark of the branch bearing good settlement of the Lac insects. Three such slots were made on each plant. Each slot was designated as $S_{1}, S_{2}$, and $S_{3}$. Stretching a thread between the index fingers of both the hands, the insects settled adjacent to the boundaries of the slot was carefully removed to make the slot clearly differentiate from the rest of the Lac insect settlement on the branch.

\section{Digital recording}

The crawlers of Lac insect are initially about $0.5 \mathrm{~mm}$ in size. It is difficult to count from a small area of $2.5 \mathrm{~cm}^{2}$ slot. And if the size of the slot is increased, there will be again difficulty in counting more insects per slot. Therefore the Lac insect settlement within the slot was digitally photographed with the help of a Digital Single Lens Reflex (DSLR) camera fitted with $100 \mathrm{~mm}$ micro lens by settling it in manual mode with ISO 400 and shutter speed of 4.5 to 6 . Several pictures of the slot was taken for clarity, finally the best click is selected.

\section{Digital counting}

The selected sets of best digital images from the DSLR camera were transferred to the Laptop, with the help of memory card reader. The images were opened in the "Paint 3D" programme of the Microsoft Office 10 (Plate). After enlarging the image on the screen of the Laptop, the "Brush tool" on the Tool bar of the Paint 3D programme was selected. This was followed by selecting the thickness point of the Calligraphy pen from $1 \mathrm{x}$ to $18 \mathrm{x}$ as well as the contrast colour of the Brush tool.

Placing the cursor on the individual Lac insect within the slot on the image displayed on the computer screen, when a left click of the mouse is done, a dot of the selected thickness and colour appears on the image of the selected insect in the screen. The process was 
followed till all the Lac insects in the slot had a dot on it. All the dots were then counted and recorded, followed by saving the image in a designated folder after renaming it, for retrieval in future (Patent appl.no.201921007852A).

Frequency of Lac insect count: Counting of Lac insects within the slots was done on $65^{\text {th }}$, $95^{\text {th }}, 125^{\text {th }}, 155^{\text {th }}$ and $185^{\text {th }}$ day after BLI.

Emergence of male Lac insects: The date of emergence of adult male Lac insects as well as duration of its presence on the Lac insect settlement was recorded.

Flower removal: Flower removal was carried out in the respective treatments at flower initiation phase (i.e.90 DAT).

Pod removal: Pod removal from the $C$. cajan in the specific treatments of the experiment, was done at pod initiation stages. (i.e.120DAT). Young pods were removed before grain formation filling stage during the growth season.

Data analysis: Data of the parameters were analysed. The significance among different treatment means was judged by critical difference (C.D) at 5\% level of significance for comparison, for which the marginal means of each treatment was considered. The following formula was used for various estimations.

Standard error of mean SEm $\pm=\sqrt{\frac{E M S}{r}}$

Critical difference (C.D.) $=\operatorname{SEm} \pm x \sqrt{ } 2 \times \mathrm{t}$ 0.05

where, EMS = error mean sum of square, $\mathrm{t}=$ ' $\mathrm{t}$ ' value at $5 \%$ level at error d.f., $r=$ number of replications, SEm $\pm=$ standard error of any treatment mean, $\mathrm{CD}=$ Critical difference.

\section{Results and Discussion}

Mean live Lac insects (MNL) per $2.5 \mathrm{~cm}^{2}$ on $65^{\text {th }}$ day after BLI (07.01.2019)

On $65^{\text {th }}$ day of BLI the MNL per $2.5 \mathrm{~cm}^{2}$ of branches was maximum (211.61) in T5 (C.cajan grown on $\mathrm{S}_{3}$ with Lac insects and hand picking of mature pods), while it was minimum (147.00) (Table 2) in T1 (C. cajan grown on $\mathrm{S}_{1}$ with $\mathrm{Lac}$ insects and hand picking of mature pods). At $65^{\text {th }}$ day of BLI, plants were in its growth stage, there was no flower bud initiation at this stage of the crop. Though T5 was significantly highest over T1, but was at par with rest of the treatments.

Counting of live Lac insects in a unit space of $2.5 \mathrm{~cm}^{2}(2.5 \mathrm{~cm}$ long and $1.0 \mathrm{~cm}$ width $)$ space on the Lac insect settled branches is considered as a standard as suggested by earlier workers viz., Vajpayee et al., (2019) Khobragade, (2010), Rathore, (2011), Patel, (2013), Bhalerao, (2013), Shah et al., (2014), Sharma et al., (2015), Gurjar, (2016), Ghugal et al., (2016), Namdev et al., (2015), Jhanghel (2014), Mohanta et al., (2014), Kalahal et al., (2017), Sharma et al., (2018).

However, Hazarika et al., (2018) has reported Lac insect count from $1 \mathrm{~cm}^{2}$. Counting of larvae insects of size varying from 0.2 to $0.5 \mathrm{~mm}$ within a small space of $1 \mathrm{~cm}$ is extremely difficult in field condition; while from $2.5 \mathrm{~cm}^{2}$ is quite comfortable.

\section{MNL per $2.5 \mathrm{~cm}^{2}$ on $95^{\text {th }}$ day after BLI}

On $95^{\text {th }}$ day of BLI the MNL per $2.5 \mathrm{~cm}^{2}$ of branches was again maximum (155.33) in T5 but it was minimum (119.78) in T3 (C. cajan grown on $\mathrm{S}_{1}$ with Lac insects and removal of flowers). It was significantly highest in T5 over T3. However, rest of the treatments was at par with each other. 


\section{MNL per $2.5 \mathrm{~cm}^{2}$ on $125^{\text {th }}$ day after BLI}

On $125^{\text {th }}$ day of BLI the MNL per $2.5 \mathrm{~cm}^{2}$ of branches continuedto be maximum (143.39) in T5 but it was minimum (104.00) in T2 (C.cajan grown on $\mathrm{S}_{2}$ with Lac insects and hand picking of mature pods) on $125^{\text {th }}$ day of BLI. It was significantly highest in T5 over T3. However, rest of the treatments was at par with each other.

\section{MNL per $2.5 \mathrm{~cm}^{2}$ on $155^{\text {th }}$ day after BLI}

On $155^{\text {th }}$ day of BLI the MNL per $2.5 \mathrm{~cm}^{2}$ was highest (109.67) in T5 and lowest (81.72) in T2.It was significantly highest in T5 over T2. However, rest of the treatments it was at par with each other.

\section{MNL per $2.5 \mathrm{~cm}^{2}$ on $185^{\text {th }}$ day after BLI}

On $185^{\text {th }}$ day of BLI the MNL per $2.5 \mathrm{~cm}^{2}$ of branches was highest (71.72) in T6 (C. cajan grown on $\mathrm{S}_{1}$ with Lac insects and removal of young pods) and lowest (51.39) in T2 (C.cajan grown on $S_{2}$ with Lac insects and picking of mature pods). There was significant difference in the MNL per $2.5 \mathrm{~cm}^{2}$ in all treatments over T2.

The MNL in different treatments is reported to vary from 60 to 95.80 (Patel, 2013), 28.13 to 40.53 (Jhanghel, 2013), 51.35 to 64.08 (Namdev, 2014), 38.31 to 43.37 (Gurjar, 2016), 37.05 to 39.34 (Kumar et al., 2017) and 57.48 to 64.08 (Shah et al., 2018). During different growth period the MNL varied in the previous studies as there was a variation in the host, season, Lac insect strain, location and treatments in their studies. However, these studies indicate a universal decline in the trend of the MNL per $2.5 \mathrm{~cm}^{2}$ during its growth phases in comparison to that occurred at BLI. Thus the MNL per $2.5 \mathrm{~cm}^{2}$ continuously decreased from $65^{\text {th }}$ days of BLI to $185^{\text {th }}$ dayof $\mathrm{BLI}$, irrespectively of the treatments except T4 (with no Lac insect) the mean percent of MNL at $185^{\text {th }}$ day over $65^{\text {th }}$ day of BLI was highest $(41.83 \%)$ in $\mathrm{T} 1$ while it was least $(31.72 \%)$ in T2. Lac insects were protected from parasites and predators by the application of contact insecticides. Thus, the loss of the Lac insect may be due to its natural death.

\section{Survival of Lac insects at different treatments}

We have to understand that among many of the deciding factors for the Lac crop productivity, the percent survival of Lac insects from the BLI to harvest is one of the important factors. It is because $\mathrm{Lac}$ is produced by female Lac insects. Now, there are again different substrates that can play a vital role in Lac production. The emergence and presence of male Lac insects, in the Lac ecosystem is one sub factor while another sub factor is the loss in the number of Lac insects before and after emergence of the male Lac insects. This matter though be discussed later, but the data must be looked with that perspective.

The percent survival of Lac insects is reported here is in three phases of Lac insect growth after BLI. The duration between $65^{\text {th }}$ and $125^{\text {th }}$ day of BLI is usually larval growth and pupal period of the Baishakhi crop of Rangeeni Lac insects. Male emergence and mating takes place between $125^{\text {th }}$ and $155^{\text {th }}$ day of BLI while the major Lac secretion phase is after mating of female Lac insect i.e., $155^{\text {th }}$ day onwards in case of Baishakhi crop of Rangeeni Lac. Between $65^{\text {th }}$ to $95^{\text {th }}$ day after BLI, the maximum survival of Lac insects was 86.24 percent in $\mathrm{T}_{1}$ (C. cajan grown on $\mathrm{S}_{1}$ with Lac insects and hand picking of mature pods) followed by 84.03 percent in $\mathrm{T} 7(C$. cajan grown on $\mathrm{S}_{1}$ with Lac insects and only one picking of mature pods followed by removal of flowers). 
Table.1 The details of the treatments and notations used are as below

\begin{tabular}{|c|l|}
\hline Treatment number & \multicolumn{1}{|c|}{ Treatment details } \\
\hline $\mathbf{T}_{\mathbf{1}}$ & C. cajan grown on $\mathrm{S}_{1}$ with Lac insects with hand picking of pods \\
\hline $\mathbf{T}_{\mathbf{2}}$ & C.cajangrown on $\mathrm{S}_{2}$ with Lac insects with hand picking of pods \\
\hline $\mathbf{T}_{\mathbf{3}}$ & C.cajan grown on $\mathrm{S}_{1}$ with Lac insects and removal of flowers \\
\hline $\mathbf{T}_{\mathbf{4}}$ & C.cajan grown on $\mathrm{S}_{1}$ without Lac insects with hand picking pods \\
\hline $\mathbf{T}_{\mathbf{5}}$ & C.cajan grown on $\mathrm{S}_{3}$ with Lac insects with hand picking pods \\
\hline $\mathbf{T}_{\mathbf{6}}$ & C. cajan grown on $\mathrm{S}_{1}$ with Lac insects and removal of young pods \\
\hline $\mathbf{T}_{\mathbf{7}}$ & $\begin{array}{l}\text { C. cajan } \text { grown on } \mathrm{S}_{1} \text { with Lac insects and only one hand picking of } \\
\text { mature pods followed by removal of flowers }\end{array}$ \\
\hline
\end{tabular}

Table.2 Mean number of live Lac insects settled per $2.5 \mathrm{~cm}^{2}$ on the $C$. cajan branches under different treatments

\begin{tabular}{|c|c|c|c|c|c|c|}
\hline \multirow[t]{2}{*}{ Treatments } & \multicolumn{6}{|c|}{$\begin{array}{l}\text { Mean no. of Lac insects settlement per } 2.5 \mathrm{~cm}^{2} \text { on days after } \\
\text { BLI }\end{array}$} \\
\hline & $\begin{array}{c}65 \\
\text { Days }\end{array}$ & $\begin{array}{c}95 \\
\text { Days }\end{array}$ & $\begin{array}{c}125 \\
\text { Days }\end{array}$ & $\begin{array}{c}155 \\
\text { Days }\end{array}$ & $\begin{array}{c}185 \\
\text { Days }\end{array}$ & $\begin{array}{l}\text { Surviv } \\
\text { al \% }\end{array}$ \\
\hline $\begin{array}{l}\mathrm{T}_{1}-\text { C. cajan grown on } \mathrm{S}_{1} \text { with Lac } \\
\text { insects and hand picking of } \\
\text { mature pods }\end{array}$ & $\begin{array}{l}\mathbf{1 4 7 . 0 0} \\
(12.07)\end{array}$ & $\begin{array}{l}\mathbf{1 2 6 . 7 8} \\
(11.22)\end{array}$ & $\begin{array}{l}\mathbf{1 0 7 . 2 8} \\
(10.37)\end{array}$ & $\begin{array}{l}\mathbf{8 6 . 3 3} \\
(9.30)\end{array}$ & $\begin{array}{l}61.50 \\
(7.87)\end{array}$ & 41.83 \\
\hline $\begin{array}{l}\mathrm{T}_{2^{-}} \text {C.cajan grown on } \mathrm{S}_{2} \text { with Lac } \\
\text { insects and hand picking of } \\
\text { mature pods }\end{array}$ & $\begin{array}{l}\mathbf{1 6 2 . 0 0} \\
(12.70)\end{array}$ & $\begin{array}{l}\mathbf{1 2 3 . 1 1} \\
(11.11)\end{array}$ & $\begin{array}{l}\mathbf{1 0 4 . 0 0} \\
(10.20)\end{array}$ & $\begin{array}{l}81.72 \\
(9.05)\end{array}$ & $\begin{array}{l}\mathbf{5 1 . 3 9} \\
(7.20)\end{array}$ & 31.72 \\
\hline $\begin{array}{l}T_{3^{-}} \text {C.cajan grown on } S_{1} \text { with Lac } \\
\text { insects and removal of flowers }\end{array}$ & $\begin{array}{l}\mathbf{1 6 3 . 7 2} \\
(12.73)\end{array}$ & $\begin{array}{l}\mathbf{1 1 9 . 7 8} \\
(10.90)\end{array}$ & $\begin{array}{l}\mathbf{1 0 6 . 3 9} \\
(10.28)\end{array}$ & $\begin{array}{l}\mathbf{8 7 . 0 0} \\
(9.31)\end{array}$ & $\begin{array}{l}62.89 \\
(7.94)\end{array}$ & 38.41 \\
\hline $\begin{array}{l}T_{4^{-}} \text {C.cajan grown on } S_{1} \text { without } \\
\text { Lac insects and hand picking of } \\
\text { mature pods }\end{array}$ & $\begin{array}{l}\mathbf{0 . 0 0} \\
(0.71)\end{array}$ & $\begin{array}{l}\mathbf{0 . 0 0} \\
(0.71)\end{array}$ & $\begin{array}{l}\mathbf{0 . 0 0} \\
(0.71)\end{array}$ & $\begin{array}{l}\mathbf{0 . 0 0} \\
(0.71)\end{array}$ & $\begin{array}{l}\mathbf{0 . 0 0} \\
(0.71)\end{array}$ & 0.00 \\
\hline $\begin{array}{l}T_{5^{-}} \text {C.cajan grown on } \mathrm{S}_{3} \text { with Lac } \\
\text { insects and hand picking of } \\
\text { mature pods }\end{array}$ & $\begin{array}{l}211.61 \\
(14.55)\end{array}$ & $\begin{array}{l}\mathbf{1 5 5 . 3 3} \\
(12.47)\end{array}$ & $\begin{array}{l}\mathbf{1 4 3 . 3 9} \\
(11.98)\end{array}$ & $\begin{array}{l}\mathbf{1 0 9 . 6 7} \\
(10.49)\end{array}$ & $\begin{array}{l}71.61 \\
(8.49)\end{array}$ & 33.84 \\
\hline $\begin{array}{l}T_{6^{-}} \text {C. cajan grown on } \mathrm{S}_{1} \text { with Lac } \\
\text { insects and removal of young pods }\end{array}$ & $\begin{array}{l}\mathbf{1 8 4 . 8 9} \\
(13.45)\end{array}$ & $\begin{array}{l}\mathbf{1 5 0 . 2 8} \\
(12.20)\end{array}$ & $\begin{array}{l}\mathbf{1 3 0 . 7 8} \\
(11.40)\end{array}$ & $\begin{array}{l}\mathbf{1 0 2 . 0 6} \\
(10.10)\end{array}$ & $\begin{array}{l}71.72 \\
(8.49)\end{array}$ & 38.79 \\
\hline $\begin{array}{l}\mathrm{T}_{7^{-}} \text {C. cajan grown on } \mathrm{S}_{1} \text { with Lac } \\
\text { insectsand only one hand picking } \\
\text { of mature pods followed by } \\
\text { removal of flowers }\end{array}$ & $\begin{array}{l}\mathbf{1 5 1 . 7 2} \\
(12.27)\end{array}$ & $\begin{array}{l}\mathbf{1 2 7 . 5 0} \\
(11.26)\end{array}$ & $\begin{array}{l}\mathbf{1 1 6 . 6 7} \\
(10.77)\end{array}$ & $\begin{array}{l}90.28 \\
(9.49)\end{array}$ & $\begin{array}{l}\mathbf{6 3 . 4 4} \\
(7.97)\end{array}$ & 41.81 \\
\hline $\mathbf{S E}(\mathbf{m}) \pm$ & 0.63 & 0.50 & 0.44 & 0.34 & 0.20 & \\
\hline CD at $5 \%$ & 1.94 & 1.56 & 1.38 & 1.05 & 0.62 & \\
\hline
\end{tabular}

Figure in parenthesis are transformed value $\sqrt{x+0.5}$ 
Table.3 Physico-chemical properties of the substrate (65kg) filled in Poly propylene bag (PPB)

\begin{tabular}{|l|c|lr|}
\hline Parameters & $\begin{array}{c}\text { Value } \\
\text { (g/65kg substrate) }\end{array}$ & Method used & \\
\hline Available $\mathbf{N}$ & 136.15 & $\begin{array}{l}\text { Alkaline permanganate method } \\
\text { (Subbiah and Asija,1956) }\end{array}$ \\
\hline Available $\mathbf{P}_{2} \mathbf{O}_{\mathbf{5}}$ & 45 & $\begin{array}{l}\text { Calorimeter method (Olsen et } \\
\text { al.,1954 }\end{array}$ \\
\hline Available $\mathbf{K}_{\mathbf{2}} \mathbf{O}$ & 304 & $\begin{array}{l}\text { Flame Photometer method } \\
\text { (Chapman and Pratt, 1961) }\end{array}$ \\
\hline
\end{tabular}

Table.4 Percent of loss in the MNL Lac insects per $2.5 \mathrm{~cm}^{2}$

\begin{tabular}{|c|c|c|c|c|}
\hline \multirow[t]{2}{*}{ Treatments } & \multicolumn{4}{|c|}{$\begin{array}{l}\text { Percent of loss in MNL per } 2.5 \mathrm{~cm}^{2} \text { at different periods after } \\
\text { BLI }\end{array}$} \\
\hline & $\begin{array}{l}65^{\text {th }} \text { to } 95^{\text {th }} \\
\text { Day }\end{array}$ & $\begin{array}{l}65^{\text {th }} \text { to } 125^{\text {th }} \\
\text { Day }\end{array}$ & $\begin{array}{l}65^{\text {th }} \text { to } 155^{\text {th }} \\
\text { Day }\end{array}$ & $\begin{array}{l}65^{\text {th }} \text { to } 185^{\text {th }} \\
\text { Day }\end{array}$ \\
\hline $\begin{array}{l}T_{1-} \text { C. cajan grown on } S_{1} \text { with Lac insects } \\
\text { and hand picking of mature pods }\end{array}$ & 13.76 & 27.02 & 41.27 & 58.16 \\
\hline $\begin{array}{l}T_{2^{-}} \text {C.cajan grown on } S_{2} \text { with Lac insects } \\
\text { and hand picking of mature pods }\end{array}$ & 24.01 & 35.80 & 49.55 & 68.28 \\
\hline $\begin{array}{l}T_{3^{-}} \text {C.cajan grown on } S_{1} \text { with Lac insects } \\
\text { and removal of flowers }\end{array}$ & 26.84 & 35.02 & 46.86 & 61.59 \\
\hline $\begin{array}{l}T_{4-} \text { C.cajan grown on } S_{1} \text { without Lac insects } \\
\text { and hand picking of mature pods }\end{array}$ & - & - & - & - \\
\hline $\begin{array}{l}T_{5^{-}} \text {C.cajan grown on } S_{3} \text { with Lac insects } \\
\text { and hand picking of mature pods }\end{array}$ & 26.59 & 32.24 & 48.18 & 66.16 \\
\hline $\begin{array}{l}T_{6^{-}} \text {C. cajan grown on } S_{1} \text { with Lac insects } \\
\text { and removal of young pods }\end{array}$ & 18.72 & 29.27 & 44.80 & 61.21 \\
\hline $\begin{array}{l}T_{7^{-}} C \text {. cajan grown on } S_{1} \text { with Lac } \\
\text { insectsand only one hand picking of mature } \\
\text { pods followed by removal of flowers }\end{array}$ & 15.96 & 23.11 & 40.50 & 58.18 \\
\hline
\end{tabular}

The lowest percent $(73.40 \%)$ survival of Lac insect during this period was in T5 (C.cajan grown on $\mathrm{S}_{3}$ with $\mathrm{Lac}$ insects with hand picking of mature pods). In comparison to the MNLbetween65 ${ }^{\text {th }}$ and $95^{\text {th }}$ day after BLI the maximum survival of Lac insects between the $65^{\text {th }}$ and $125^{\text {th }}$ day period was 76.89 and 72.97 percent in $\mathrm{T} 7$ (C. cajan grown on $\mathrm{S}_{1}$ with Lac insects and only one hand picking of mature pods followed by removal of flowers) and T1 (C. cajan grown on $\mathrm{S}_{1}$ with $\mathrm{Lac}$ insects and hand picking of mature pods) respectively. The lowest percent $(64.19 \%)$ survival of Lac insects during this period was in T2 (C.cajan grown on $S_{2}$ with Lac insects and hand picking of mature pods).

However between $65^{\text {th }}$ to $155^{\text {th }}$ day the mean percent survival of Lac insects varied from 50.44 to 59.50 percent. Similar, the mean survival percent of Lac insects between $65^{\text {th }}$ and $185^{\text {th }}$ day insects was still higher ranging from 31.72 to 41.83 percent.

The percent loss of MNL during $65^{\text {th }}$ to $185^{\text {th }}$ day period was lowest (58.16 and $58.18 \%$ ) in T1 and T7 while highest loss of 68.27 and 66.15 percent was in T2 and T5 respectively. 
Loss of Lac insect during its growth stages is common and reported by previous workers viz., Vajpayee, (2019), Khobragade, (2010), Patel, (2013), Jhanghel, (2013), Bhalerao, (2013), Namdev, (2014), Ghugal, (2015), Gurjar, (2016), Sahu, (2016) and Shah et al., (2018). The percent loss of Lac insect from BLI to maturity or harvest varies and depends on the various conditions. The mean percent Lac insect loss ranged from 7.62 to 16.83 percent (Khobragade, 2010), while according to Patel, (2013) it ranged from 69.14 to 74.52 percent (Table 4).

In conclusion the lac insects are phloem feeders and they continuously feed on stem of the host crop. Therefore the host plant to be more vigorous in growth and healthy. So in present study used different substrate combination with bio-culture for the growth of host plant as well as Lac insects and its survival. It was found the treatment $\mathrm{T} 1(C$. cajan grown on $\mathrm{S}_{1}$ with Lac insects with hand picking of pods) was the best for $C$. cajan grain yield and Lac production also because of the combination of substrate was Kapu and FYM ratio $1: 1$ with $T$. viride. But in Treatment 3 (C.cajan grown on $\mathrm{S}_{1}$ with Lac insects and removal of flowers), the100 lac cell weight, raw Lac yield and Fuel wood was more in comparatively rest of the treatments. C. cajan can be successfully grown on substrate treated with soil microbes in PPB.K. lacca influence the plant growth in comparison to $C$. cajan grown on S2 (FYM only) T2 to that S1 (Kapu and FYM) T1, there was an increase in plant height, thicknesses of stem, primary branches, secondary branches and these growth indicators showed positive effects on Lac insects survival. Maximum settlement of $K$. lacca was on secondary branches.

\section{References}

Ayres JS, Schneider DS. 2009. The role of anorexia in resistance and tolerance to infections in Drosophila. PLoSBiol; 7:1000- 1005 .

Bhalerao, K.R. 2013. Study on Predator surveillance and its management on Rangeeni Lac in Barghat block district Seoni Madhya Pradesh. M.Sc. (Ag.) Thesis submitted in JNKVV, Jabalpur.

Colton HS. 1984. The anatomy of the female American Lac insect Tachardiella larea Bull. Mus. Nth. Arizona Flagstaff 21:1-24.

Douglas AE. 2003. Nutritional physiology of aphids. Advances in Insect Physiology 31: 73- 140.

Ghugal SG, Thomas M., Upadhyay A and HL Sharma. 2016. Foliar Application of Nutrients and PGR on Butea monosperma and Survival of Kerria lacca (Kerr). Advances in Life Sciences 5(1): 159-163.

Gimnig JE, Ombok M, Otieno S, Kaufman MG, Vulule JM and Walker ED. 2002. Density-dependent development of Anopheles gambiae (Diptera: Culicidae) larvae in artificial habitats. J Med Entomology, 39:162-172

Godfery LD, Keillor K, Hutmacher RB and Cisneros JJ. 1999. Interaction of cotton aphid population dynamics and cotton fertilization regime in California. Cotton Proceeding Belt wide Cotton Conference, Orlando, Florida, USA. 1999; 2:1008-1011.

Gogi MD, Arif JM, Asif M, Abdin Z, Bashir HM and Arshad M. 2012.Impact of nutrient management schedules on infestation of Bemisia tabaci on and yield of non BT cotton (Gossypium hirsutum) under unsprayed conditions. Pakistan Entomologist 34(1): 87-92

Gurjar R. 2016. Study on the Effect of Foliar Application of Nitrogen and PGR on Butea monosperma on Katki Crop Production. M.Sc. Thesis. Jawaharlal Nehru Krishi Vishwa Vidyalaya, Jabalpur, M.P. 
Heinrichs EA and Barrion AT.2004. Rice feeding insects and selected natural enemies in West Africa biology. Ecology, Identification.

Janghel S, Thomas M, Thakur AS, Nema S, and Sharma HL. 2014. Study on Bio Efficacy of Insecticides in the Predator Management of Katki Lac Crop Bioengineering and Bioscience 2(2): 15-22.

Janghel SK, Thomas M, Thakur AS and Nema S. 2016. Evaluation of Newer Insecticides for Predator Management of Kerria lacca (Kerr). Indian Journal of Ecology 43.

Kaiwei H, Jinyuan L, Fengshu L, and Peng Y. 1988. The effect of getting rid of flower buds on the yield and quality of brood Lac. Forest Research 1(1): 4146.

Kalahal C, Swami H and Lekha. 2017. Productivity-linked parameters of the Rangeeni strain Lac Insect, Kerria lacca Kerr. on Pigeonpea, C cajan Linn. at Rajasthan. Journal of Entomology and Zoology Studies; 5(3): 1745-1751.

Kaushik S, Pushker AK, Lakhanpaul S, Sharma KK and Ramani R. 2012. Investigations on some of the important host plants of Kerria lacca with reference to phloem distance. Eur Asian Journal of Biosciences 6: 32-38.

Kehr, J. 2006. Phloem sap proteins: their identities and potential roles in the interaction between plants and phloem-feeding insects. Journal of Experimental Botany, Vol. 57, No. 4, pp. 767-774, doi:10.1093/jxb/erj087 Advance Access publication 22 February, 2006

Kumar A and Rani M. 2019.Kerria lacca, Flemingia macrophylla, NPK fertilizer: plant growth, Lac yield, Lac parastisation European Journal of Biological Research 2019; 9(4): 259-
266

Kurmi A, Thomas M, Namdev BK, Sheela S. and Pachori R. 2015.Lacinsect associated ants and their distribution in Laceco-systems of Madhya Pradesh. International Journal of Agriculture sciences, volume 7, Issue 15, pp.-915917.

Mallikarjuna N, Saxena KB and Jadhav DR. 2011. Cajanus. In: Chittaranjan, K. (Eds). Wild crop relatives: genomic and breeding resources - legume crops and forages. Springer-Verlag Berlin Heidelberg.

McGuinness H. 1987. The importance of plant diversity and the nutritional content of the diet on the population dynamics of herbivorous insects. $\mathrm{PhD}$ Dissertation. Biology Department, the University of Michigan, Ann Arbor, MI, 1987

Mengel, K. and Kirkby, EA. 1987. Principles of plant nutrition.4th edition. International Potash Institute, Basel, Switzerland.687 pp.

Mohanta J, Dey DG and Mohanty N. 2014. Studies on Lac insect (Kerria lacca) for conservation of biodiversity in Similipal Biosphere Reserve, Odisha, India. Journal of Entomology and Zoology Studies: 2 (1): 1-5.

Namdev BK, Thomas M, Kurmi A, Thakur AS, Updhyayay A. Impact of Nutrient Management of Zizyphus mauritiana (Lamb.) on the yield of kusmi Lac. The Bioscan. 2015; 10(3):1219-1222.

Okech BA, Gouagna LC, Yan G, Githure JI and Beier JC. 2007. Larval habitat of Anopheles gambiaes. (Diptera: Culicidae) influences vector competence to Plasmodium falciparum parasite. Malar J 2007, 6:50

Potter DA and Held DW. 2002. Biology and management of the Japanese beetle. Ann. Rev. Entomol. 47:175-205.

Roonwal ML, Raizada MB, Chatterjee RN 
and Singh B. 1958. Descripitive account of the host plants of the Lac insect, Lacciferlacca (kerr) and the allied plants in the Indian Region, Indian LacCess Committee, Ranchi. pp. 157-179.

Ruiz-Medrano R, Xoconostle-Cazares B and Lucas WJ. 2001. The phloem as a conduit for inter-organ communication. Current Opinion in Plant Biology 4, 202-209

Shah TH, Thomas $\mathrm{M}$ and Bhandari $\mathrm{R}$. 2014.Impact of nutrient management in Z.mauritiana (Lamb.) on the survivability of Lac insect and the yield of Aghani crop of Kusmi Lac. Journal of Entomology and Zoology Studies, 2(5):160-163

Shah TH, Thomas M and Bhandari R. 2015. Lac production, constraints and management. International Journal of
Current Research 7(3): 13652-13659. Sharma H, Ghugal SG, Thomas M. and Pachori R. 2015.Impact of Nutrient Management in Butea monosperma (Lam.) Taub. on the Survivability of Kerria lacca (Kerr). An International Quarterly Journal of Life Science 8 (23): 6682-6687

Thomas JG. 1992. Pest Management in Integrated Pest Management. United States Council on Environmental Qualitites. Washington DC. pp.165.

Thomas M. 2003. Lac to Lakhs, Reviving self reliance, KVK Shahdol 1-20.

Yumamura K, Yokazawa M, Nishimori M, Ueda Y, Yokosuka T. 2006. How to analyse long- term insect population dynamics under climate change: 50 year data of three insect pests in paddy fields. Population Ecol; 48:38-48.

\section{How to cite this article:}

Sumit Kakade, Rahul Patidar, Shivam Vajpayee, Moni Thomas, Niraj Tripathi, A. K. Bhowmick, Anubha Upadhyay, A. K. Mandal, H. L. Sharma and Sanjay Singh. 2020. Survival of Lac Insects (Kerria lacca Kerr.) on Cajanus cajan (L) Millsp.. Int.J.Curr.Microbiol.App.Sci. 9(12): 173-182. doi: https://doi.org/10.20546/ijcmas.2020.912.024 